\title{
Tek Parti Döneminde Jandarma Teşkilatının Durumu (1923-1946)
}

\author{
Cengiz ATLI ${ }^{1}$
}

\section{$\ddot{O} z$}

Bu dönemde Jandarma teşkilatı özellikle Doğu ve Güneydoğu Anadolu da başlayan iç isyanlarla uğraştı. Ordunun diğer unsurları gibi jandarma teşkilatı da çok zor şartlar altında görev yaptı. Jandarma Teşkilatında sıhhi işleri görecek yeterli birim yoktu. Genellikle açık alanda görev yaptıkları için salgın hastalıklar ve özellikle sıtma hastalığından dolayı teşkilatta büyük sıkıntılar yaşanıyordu. Silah ve motorlu araç bakımından da yeterli sayı yoktu. Jandarma Teşkilatında olumsuz imkânlarını düzenlemek amacıyla 10 Haziran 1930 tarihinde 1706 sayılı Jandarma Kanun çıkarılmış ve Jandarma Teşkilatı bu günkü hukuki statüsünü kazanmıștı.1935 yılında Jandarma subaylarının Harp Okulu'nda yetiştirilmesi esası kabul edilmiştir.1937 yılında 'Jandarma Teşkilat ve Vazife Nizamnamesi' yürürlüğe girmiştir.1939 yılında Jandarma Teşkilatı; Sabit Jandarma Birlikleri, Seyyar Jandarma Birlikleri, Jandarma Eğitim Birlikleri ve Okullar olmak üzere dört grup halinde yeniden düzenlenmiştir. Jandarmanın bu dönemde yaptığ1 çalışmalar incelendiğinde teşkilât yapısında birçok değişiklik olmasına rağmen görev bilinci hiç değişmemiştir. Bu süreç içeresinde ülkenin iç güvenliğinin sağlanmasında tüm zorluklara rağmen üzerine düşen görevi başarı ile yerine getirmiştir. Makalenin konusu içerisinde jandarma teşkilatının bütçe durumu, araç durumu, kaçakç1lıkla mücadele, sıhhi durum, lojistik durum, personel durumu ve jandarma teşkilatının umumi müfettişlikler çerçevesinde yaptığı çalışmalar Başkanlık Cumhuriyet Arşivi, (BCA) dönemin gazeteleri, meclis resmi evrakları, hatıratlar ve bilimsel kaynaklar doğrultusunda analiz edilerek değerlendirilmeye çalışılmıştır.

Anabtar Kelimeler: Jandarma, Asayiş, Güvenlik, Cumhuriyet, Teşkilat

\section{The State of Gendarmerie in Single-Party Government (1923-1946)}

\begin{abstract}
During this period, the Gendarmerie had to deal with internal rebellions, especially in Eastern and Southeastern Anatolia. Like other elements of the army, the gendarmerie served under very difficult conditions. There were not enough units in the gendarmerie to perform sanitary works. Since they were generally working outdoors, there were major problems in the organization due to epidemics and especially malaria. There was not enough number of weapons and motor vehicles. In order to regulate the negative possibilities of the gendarmerie, Law No. 1706 was enacted on 10 June 1930 and the Gendarmerie Organization gained its legal status. In 1935, the Gendarmerie Officers were trained at the Military Academy. In 1937, the Gendarmerie Organization and Duties Regulation came into force. Fixed Gendarmerie Units, Mobile Gendarmerie Units, Gendarmerie Training Units and Schools. When the activities of the gendarmerie during this period were examined, although there were many changes in the organizational structure, the duty consciousness did not change at all. In this process, despite all the difficulties in ensuring the internal security of the country has fulfilled its duty successfully. Gendarmerie's budget status, vehicle status, anti-smuggling, sanitary status, logistic situation, personnel situation and the activities of the gendarmerie within the scope of the public inspectors within the scope of the article are analyzed in accordance with the Presidential Republican Archives (BCA) newspapers, parliamentary official documents, memories and scientific sources were evaluated.
\end{abstract}

Key Words: Gendarme, Public Order, Security, Republic, Organization

\section{Atıf İçin / Please Cite As:}

Atlı, C. (2020). Tek parti döneminde jandarma teşkilatının durumu (1923-1946). Manas Sosyal Arastırmalar Dergisi, 9(3), 1897-1912.

Geliş Tarihi / Received Date: 29.05.2019

Kabul Tarihi / Accepted Date: 20.02.2020

\footnotetext{
${ }_{1}^{1}$ Doç. Dr. - Iğdır Üniversitesi Fen/Edebiyat Fakültesi Tarih Bölümü cengiz3636@hotmail.com - ORCID: 0000-0001-7617-6879
} 


\section{Giriş}

Jandarma Teşkilatı 3 Kasım 1839'da Tanzimat Fermanı'nın emniyet can, 1rz ve namus ve malların korunması ile ilgili maddesine uyularak merkez teşkilatı bulunmayan subayların illerde görev almasıyla kurulmuştur. Başlangıç yllı 1839, gün olarakta Asakir-i Zaptiye Nizamnamesi’nin kabul tarihi olan 14 Haziran (ile birleştirilerek) Jandarma Teşkilat günü olarak kabul edilmiştir (Jandarma Genel Komutanlı̆g Tarihi, s. 132.)

1870 yılına kadar Osmanlı İmparatorluğu dahilinde emniyet ve asayiş işleriyle meşgul olacak bağımsız bir kuruluş mevcut değildi. Bu tarihe kadar İstanbul'un asayişi devletin Hassa Ordusu mahiyetinde olan yeniçeri kıtasından ayrılmış kuvvetler tarafından, eyaletlerin asayişi de valilerin hazari kuvvetlerini teşkil eden milis askerler tarafindan temin ediliyordu. Genel bir kumanda ve kanun mevcut değildi. 1870 li yıllarda kurulmuş bir jandarma teşkilatı varise de daha çok İstanbul ekseninde idi. Türk devlet teşkilatına jandarma adı tarihte ilk defa 15 Nisan 1880'de kabul edilen nizamname ile girmiştir. 1881 yllında subay sınıfı Milli Müdafaa Nezareti'nin bir şubesi haline getirilmiş ve İngiltere'den getirilen subayların yardımı ile kuruluş ve teşkilatlanmasına başlanarak; vilayetlerin umum jandarmaları birer alay, sancaklarda tabur ve kazalarda birer bölük haline getirilmiştir. Vilayet jandarma kumandanlarına alay beyi, sancak kumandanlarına tabur ağası, kaza jandarma kumandanlarına bölük ağası, birinci mülazımlara (teğmen) bölük ağası muavini, mülazımlara jurnal emini unvanı verildi. Bölüklerde şartlara göre karakollara taksim olundu. Bu Jandarma alayları Harbiye Nezareti'ne bağlı iseler de görev noktasında valilerin emirlerine tabi olduklarından bakanlığa bağllıkları alıkoyma, silah tedariki ve iaşe noktasında idi. Bununla birlikte Harbiye Nezareti, Türkiye'nin kuzeyi Arnavutluk ile Arabistan dâhil ülkenin her tarafinda alıkoyma ve silahlandırma konularında genel bir birliktelik sağlamış ise de disiplin ve eğitim kısımlarını geliştirememişti. Jandarma alaylarının kadroları valilerin teklifleri üzerine tespit olunurdu. Havaleleri Harbiye Nezareti'nden verilirdi. Jandarmaların iaşeleri kısmen halk tarafından karşılandığı için kadronun fazlalı̆̆ı önemli değildi. $\mathrm{Bu}$ dönemde zor arazi şartlarında eşkıyalarla ve kaçakçılarla mücadele edildiği için atlı jandarma kadroları çoğunluktaydı. (BCA.030.10.128.923.6.2)Osmanlı ordusu içerisinde önemli görevlerde bulunan teşkilatın içerisinde yer alan jandarma birlikleri 1877-1878 Osmanl1-Rus Savaşı'nda önemli faaliyetlerde bulunmuştur. 1904 yllinda teşkilat bünyesinde yirmi dokuz jandarma alayı, üç zaptiye alayı, iki müstakil tabur, elli bir süvari, bir deve taburu yer almaktaydı (J. Gn. K. Tarihi, C. I, s. 135). Aynı dönemde ilk Jandarma Subay Okulu Selanik'te açılmış, 1909 yılında da Jandarma Daire-i Merkeziyesi kaldırılarak yerine Harbiye Nezareti’ne bağlı Umum Jandarma Komutanlığı kurulmuştu (Atatürk'ün Doğumunun Yüzüncü Yllında Türk Silahlı Kuvvetleri, s. 311.)

1914 yılına kadar yapılan düzenlemelerle Jandarma Teşkilatı genişletildi. 1914 yılında 1.Dünya Savaşı'nın çıkmasıyla mevcut jandarma birliklerine ilaveten 18 jandarma Taburu daha kuruldu. Jandarma birlikleri 21 Temmuz 1914 tarihinde sabit ve seyyar jandarma olarak iki kısma ayrllmıs, Birinci Dünya Savaşı yıllarında çeşitli görevler için farklı birlikler şeklinde teşkilatlandırılmışıı (Hüseyin Iş̧ı, Birinci Dünya Savaşında Seyyar Jandarma Birlikleri, s. 9). Kurulan bu taburlara kıyı gözetleme ve asayiş görevleri verildi. Bu savaşta Jandarma Teşkilatı Çanakkale, Irak, Suriye, Kafkasya ve Galiçya cephelerinde ülke savunmasına katkıda bulunmuşlardı. Savaş sırasında jandarma birliklerinin de cephe hattına gönderilmesi gündeme geldi, eksik kadronun yedek askerlerle kapatılması yoluna gidildi. Jandarma birliklerinden özellikle Bursa ve Gelibolu Seyyar Jandarma taburları Çanakkale muharebelerinde Anafartalar bölgesinde tarihe geçen önemli görevler üstlendi. Gelibolu yarımadasına gönderilen seyyar jandarma birlikleri diğer cephelerde de görev aldı. Özellikle Gelibolu Seyyar Jandarma Taburu sayıları gittikçe artan iki tümene karşı Kireçtepe'yi üç gün hiçbir yardım almadan savundu (Cumhuriyet Jandarması, s. 25). 1. Dünya Savaşı'nın en çetin muharebelerinin devam ettiği 1915 yllında 2089'u rütbeli, 43.750'si erbaş ve er olmak üzere toplam 45.839 jandarma bulunuyordu. Aynı yıl kadro artırımına gidildi ve jandarma sayısı 56.780’e ulaştı (J. Gn. K. Tarihi, C. II, s. 50-79).

Bu dönemde geçici bir jandarma kanunu yürürlüğe konmuştur. Kanun sekiz maddeden oluşmaktaydı (Kanun gerek merkezdeki ve gerekse illerdeki teşkilat ile ilgili genel konuları kapsamakta diğer konularda eski nizamname hükümlerinin uygulanacağı esasını getirmekteydi). Savaşın sonlarına doğru 26 Ekim 1917'de yeni bir kararname yürürlüğe konuldu. Bu kararnamede 17 maddeden oluşmaktaydı. 15 Mart 1919 tarihinde de Jandarmanın İçişleri Bakanlığına bağlanmasına dair kararname yürürlüğe konuldu (H. Alyot, Türkiye'de Zabıta, s. 328). 19 Mayıs 1919'da başlayan İstiklal Savaşı sırasında ordunun ihtiyacı olan silah ve mühimmatın işgal altındaki bölgelerden gizlice çeşitli yol ve vasıtalarla Anadolu'ya sevkinde jandarma subay ve astsubayları da görev almışı. Kurtuluş Savaşı yıllarında jandarma birlikleri hem cephe hattında hem cephe gerisinde millî orduyu destekledi. 
23 Nisan 1920'de TBMM'nin kurulmasından sonra yurdun çeşitli bölgelerinde bulunan Jandarma Teşkilatı meclisin emirlerini tüm milli mücadele boyunca yerine getirmişti 1920 yılı başlarında Ankara'da Milli Savunma Bakanlığı'na bağl1 “Umum Jandarma Komutanlığı” kuruldu. Böylece biri İstanbul'da padişahın emrinde diğeri de Ankara'da TBMM Hükümeti'nin emrinde olmak üzere iki Umum Jandarma Komutanlığ1 bulunuyordu. TBMM Hükümeti, İstanbul Hükümeti’nin yayınlamış olduğu, Jandarma Mıntıka Müfettişlikleri Talimatnamesi'ni kabul ederek, 16 Mart 1920 tarihinden itibaren İstanbul Hükümeti'nin Jandarma ile ilgili verdiği emirleri geçersiz saymıştı. 23 Nisan 1920'de TBMM'nin açılışından sonra jandarma teşkilâtı bu defa Ankara merkezli olarak düzenlenmeye çalışldı. Millî Müdafaa Vekâleti’ne bağlanan Umum Jandarma Komutanlığı, ordunun bir organı olarak sekiz bölge müfettişliği ve bu müfettişliklere bağlı illerdeki jandarma alay ve taburlarıyla yeniden teşkil edildi (Türk Silahlı Kuvvetleri Tarihi s. 391). Bölge müfettişlikleri İstanbul, Aydın, Ankara, Konya, Sivas, Adana, Trabzon ve Bitlis'te bulunuyordu. Bu dönemde eğitimini İstanbul'da sürdüren Jandarma Zâbit Mektebi de Ankara'ya nakledildi. Okul bir süre sonra Konya'ya taşındı 7 Haziran 1920'de 62 sayılı kararnâme ile piyade ve süvari sınıfından oluşan Jandarma Müfrezeleri Teşkili hakkında bir kanun yürürlüğe konuldu. Kanuna göre ülkenin iç güvenliğini sağlamak üzere Milli Müdafaa Vekâleti’ne bağlı Jandarma Müfrezeleri kuruldu. Hükümet 15 Mart 1919 tarihli kararname ile jandarmayı Dâhiliye Nezareti’ne bağladı. ( Cumhuriyet Jandarması, 21-23)Milli Mücadele Hareketi'nin ilk günlerinden itibaren gerek asayişin sağlanması gerekse milli direnişe katkısı hususunda ciddi mahiyette katkıları olan Seyyar Jandarma Müfrezeleri TBMM'nin gündemini oldukça fazla meşgul etmiştir. TBMM'de 10 Şubat 1921 tarihinde Seyyar Jandarma Müfrezeleri'nin lağvına karar verilirken yürürlük tarihi 1921 senesi Mart ayı sonu olarak kararlaştırılmıştır. Bahsi geçen müfrezelerine dair, Meclis'te görüşülen kanun teklifi Dâhiliye Vekilinin de yokluğunda hareketle fazla tartışılmadan kabul edilmiştir. 10 Şubat 1921 tarihli ve 94 sayll "Seyyar Jandarmanm Lağv Hakkinda Kanun"un 1. Maddesinde yer alan; "Müdafaai memleketin temini ve asayişi umuminin tesisi için Müdafaai Milliye vekâletine merbut olmak üzere 7 Hażiran 1336 taribli kanunla teşkili emrolunan seyyar jandarma müfrezeleri mülgadrr." hükmü ile seyyar jandarma müfrezeleri tarihe karışmıştır.

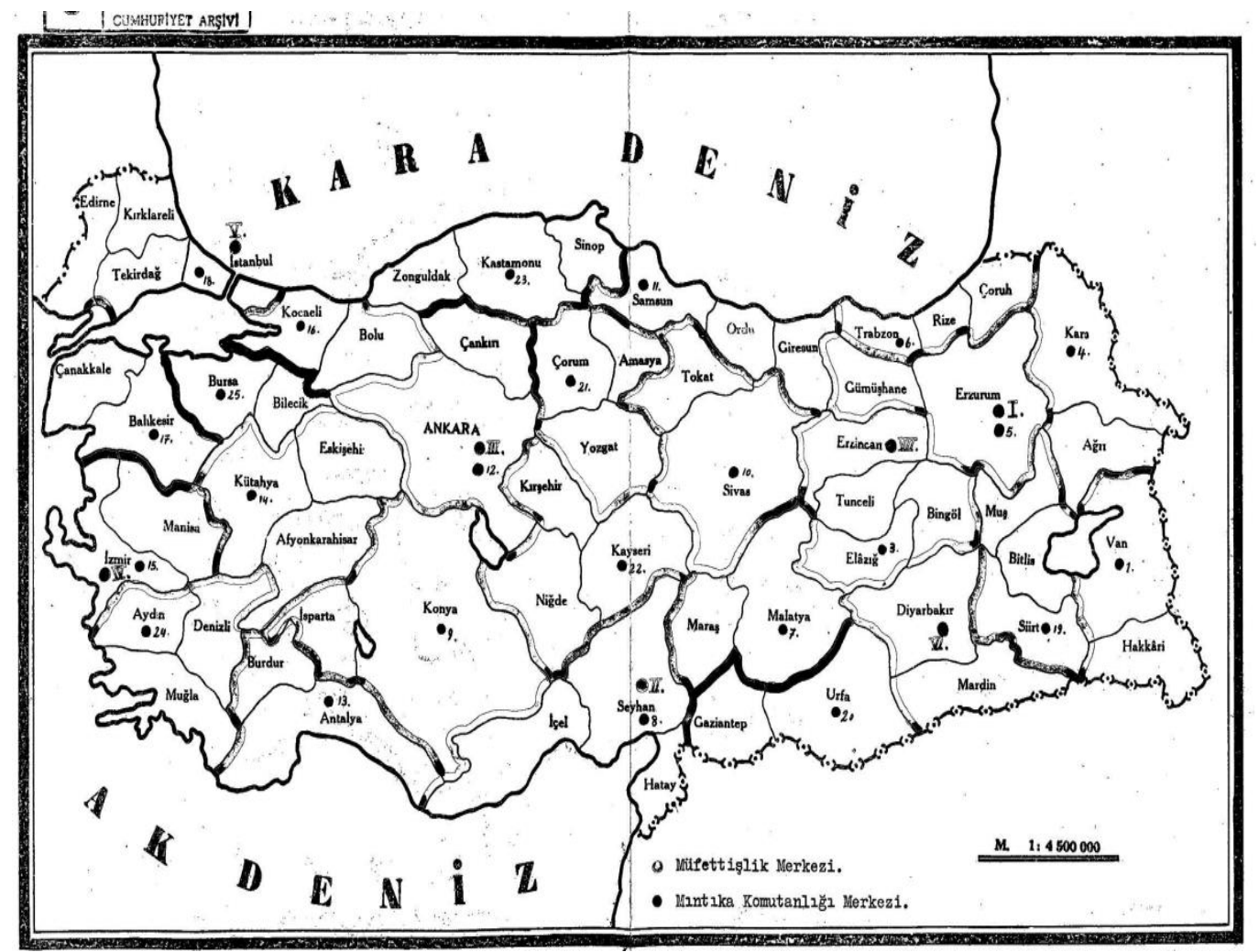

Şekil 1. Jandarma Teşkilatımn Bulunduğu Alanlar Gösteren Harita

\section{Cumhuriyet Döneminde Jandarma Teşkilatı Personel Durumu}

Ülkemizde jandarma teşkilatının düzenlenme çalışmalarına1912 yılında başlanılmıştı. Yabancı ülkelerden gelen inceleme heyetlerinin katılımıyla oluşan komisyonlar ülkenin her tarafinda incelemelerde bulunarak Jandarma Teşkilatı'nın düzenleme çerçevesini tespit etmişlerdi. Kars ve Artvin vilayetleri hariç 
olmak üzere ülkenin sabit jandarma kadrosu 1912 yllında 18.850 idi. 1913 yllında 22.070 e ve 1 . Dünya Savaşı'nın başladığı yıl olan 1914'te 28.189' a çıkarıldı. TBMM İcra Vekilleri Heyeti, 26 Mayıs 1920'de Milli Müdafaa Vekâleti’ne bağlı olmak üzere süvari ve piyadeden oluşan "Seyyar Jandarma Müfrezelerini kurmuştur. İç asayişi tek elden idare etmek isteyen TBMM Hükümeti, 12 Aralık 1920 tarihinde Umum Jandarma Kumandanlığı ile Emniyet-i Umumiye Müdüriyetini birleştirerek, Dâhiliye Vekâleti’ne bağlı bir İnzibat Umum Müdürlüğ̈̈’nü kurmuştur. Yapılan bu çalışmaların sonucunda 1922 yllı başlarında sayı 33.499a ulaştı. Cumhuriyetin ilan edilmesinde sonra 1923 yllinda 35.1031924 yillnda 33.193, 1925 yllinda 33.288 1926'da 30.286 1927'de ise say1 önemli ölçüde azalarak 28.322 olmuştur (BCA.030.10.25.166.1). 1928, 1929, 1930 kadrolar1 ise 28.303 askerden ibaretti. Hükümetin icra kuvveti ve ülkede huzurun temini olan Jandarma Teşkilatı kadro sayısı 1931 yllında 33.300, 1932 senesinde ise 34.000 rakamına ulaştı (BCA.030.10.128.823.6). Bu dönem içerisinde jandarma personel mevcutları ile okullarda yetiştirilen er mevcudu aşağıdaki tablodaki gibidir (BCA.030.01.68.1432.8).

Tablo 1. 1931-1949 Yil Jandarma Personel Mevcutlar ile Okullarda Yetiștirilen Asker Mevcudu

\begin{tabular}{lcccc}
\hline Senesi & Subay & Astsubay & Er & Er Okullarında Yetiştirilen Miktar \\
\hline 1931 & 653 & 2926 & 16.904 & 3.400 \\
1932 & 1573 & 3573 & 30.427 & 6.250 \\
1933 & 1676 & 3906 & 30.614 & 6.300 \\
1934 & 1693 & 3906 & 30.614 & 6.300 \\
1935 & 1970 & 3901 & 30.768 & 6.425 \\
1936 & 2129 & 3648 & 31.771 & 6.502 \\
1937 & 2034 & 3749 & 33.880 & 6.800 \\
1938 & 2034 & 3952 & 34.321 & 6.825 \\
1939 & 2171 & 3655 & 37.430 & 7.080 \\
1940 & 1950 & 3414 & 38.183 & 7.120 \\
1941 & 1781 & 2702 & 39.798 & 8.100 \\
1942 & 1860 & 3802 & 38.698 & 7.200 \\
1943 & 1896 & 3120 & 39.400 & 8.120 \\
1944 & 1945 & 3069 & 40.451 & 8.200 \\
1945 & 1963 & 3231 & 43.280 & 8.305 \\
1946 & 1961 & 3227 & 43.404 & 8.350 \\
1947 & 1752 & 2954 & 41.366 & 8.100 \\
1948 & 2133 & 2353 & 43.766 & 8.360 \\
1949 & 2400 & 2043 & 44.753 & 8.900 \\
\hline
\end{tabular}

Bu dönem içerisinde görev alan subay ve astsubay listesi ise aşağıdaki şekildeydi.

Tablo 2. 1923-1949 Yullarnda Subay ve Astsubay Listesi

\begin{tabular}{llll}
\hline Senesi & Subay & Astsubay & Uzatmalı Erat \\
\hline 1931 & 653 & 2926 & 227 \\
1932 & 1573 & 3573 & 236 \\
1933 & 1676 & 3906 & 311 \\
1934 & 1693 & 3906 & 327 \\
1935 & 1970 & 3901 & 339 \\
1936 & 2129 & 3648 & 452 \\
1937 & 2034 & 3749 & 489 \\
1938 & 2034 & 3952 & 505 \\
1939 & 2171 & 3655 & 568 \\
1940 & 1950 & 3414 & 596 \\
1941 & 1781 & 2702 & 603 \\
1942 & 1860 & 3802 & 657 \\
1943 & 1896 & 3120 & 678 \\
1944 & 1945 & 3069 & 693 \\
1945 & 1963 & 3231 & 711 \\
1946 & 1961 & 3227 & 737 \\
1947 & 1752 & 2954 & 766 \\
1948 & 2133 & 2353 & 797 \\
1949 & 2400 & 2043 & 992 \\
\hline
\end{tabular}

1. Dünya Savaşı'ndan sonra elde kalan subay miktarı azaldığından, subay okulları da yeterli sayıda mezun vermediğinden dolayı eksik olan subay sayısı asıl kuvvetlerin haricinde, yedekte bulundurulan subaylardan ve meslekten yetişmiş genç subayların jandarma okulunda bir sene eğitim alması suretiyle temin edilmeye çalışıldı (BCA.030.01.68.432.8.16). Çalışmalar sonucunda 1930 yılında subay sayısı $1191 \mathrm{e}$ çıktı. 1930 yılından 1946 yılına kadar yaş haddinden 180, sicil ile 121, sağlık raporu ile 62, kendi isteği ile 165 olmak üzere toplam 413 subay emekli olmuştur. 9 kişi yedek subay okuluna gönderilmiş, 9 kişi şehit 
olmuş 27 kişide vefat etmiştir (BCA.030.10.128.923.6.12). Jandarma kadrosunun güçlendirilmesi amaciyla ordudan 271 subay alınmış bu sayıdan 73 kişi tekrar orduya iade edilmiştir. 1932 yılı jandarma kadrosu 1548 subay, 182 askeri memur, 47 sağlık subayı ve memurdan ibaretti. 1936 yllında jandarma kadrosu 35.415 idi. Okullarda eğitim gören altı bin gençle, geri hizmette kullanılanlar ve doğu bölgelerinde bulunan seyyar birlikler çıkarılırsa toplam sayı 15 bin civarında idi. Umumi Müfettişliklerin kurulmasıyla I. III. ve IV. Umumi müfettişlik mıntıkasında ortalama olarak 290 diğer vilayetlerde 960 kişiye bir jandarma düşmekteydi. Karakol sayısı 2.193’tür (M. Bülent Varlık, Umumi Müfettişler Toplantı Tutanakları s. 32). Emniyet ve asayişin korunması ve kaçakçılığın önlenmesinde görevli personel oranlarında en yüksek rakam 1949 yllına ait idi. Bu yıl içerisinde 2400 subay, 5043Astsubay ve 992 uzatmalı er görev yapmaktaydı (BCA.030.01.68.432.8.3). Dönem süresince komuta kademesinde görev yapan Jandarma Komutanlarının isim listesi şöyledir.

1-Miralay Hacı Hurşit (1923-1924)

2- Tuğgeneral Ahmet Zeki ( 1924-1930)

3-Korgeneral Kazım Orbay (1930-1935)

4- Korgenaral Naci Tinaz (1935-1939)

5- Korgeneral C.Cahit Toydemir (1939-1940)

6- Korgeneral A.Riza Artunkal (1940-1941)

7- Korgeneral Rüştü Akın ( 1941-1943)

8-Korgenaral Rifat Matarac1 (1943-1945)

9- Korgeneral Nazmi Gönenli ( 1945-1947) idi. (Cumhuriyet Jandarması s. 28-29)

\section{Cumhuriyetin İlan edilmesinden sonra Jandarma Teşkilatının Yeniden Organize Edilmesi}

29 Ekim 1923'te cumhuriyetin ilan edilmesiyle birlikte jandarma teşkilatı da yeniden organize edilmeye başlandı 1918 de kapatılmış bulunan Jandarma Astsubay Okulu İzmit’te yeniden açıldı. Sabit Jandarma Bölge Müfettişlikleri ve bunların emrinde bulunan İl Jandarma Alay Komutanlıkları yeniden teşkilatlandırıldı. Cumhuriyetin ilanından sonra mevzuat yönünden en önemli gelişme 1930 yilında yaşandı. Jandarma Teşkilâtı, 22 Haziran 1930 tarih ve 1706 sayllı kanunun yürürlüğe girmesiyle önemli bir aşama kaydetti. Bu kanunla jandarmanın tanımı, görevi, bağlılık durumu, yetkileri, subayların görev ve sorumlulukları ayrıntılı biçimde tespit edildi. Kanunla Jandarma Teşkilatı günümüze kadar sürecek hukuki statüsünü kazandı (TBMMZC, 20/72/86; Resmi Gazete, 22.06.1930 No: 1526). Ayrica bu tarihte sevk ve idaresi orduya birakılan seyyar jandarma idaresinin de 1930 yllında yaşanan olaylardan dolayı sonraki yıllarda da orduya bırakılması kararlaştırıldı (BCA.030.18.01.02.19.23.11). 1935 yilında jandarma teşkilatında önemli bir gelişme yaşandı. 1706 sayılı Jandarma Kanunu uyarınca Jandarma subaylarının Harp Okulundan karşılanması esası kabul edildi. Böylece Jandarma Teşkilâtının subay ihtiyacı Harp Okulu'ndan sağlanmaya başlandı. Ankara'da Anıttepe'de 1935'te Jandarma Sınıf Okulu açıldı ve uzun yıllar Polis Enstitüsü ile ortak binada öğretime devam edildi.1935 yllındaki yeni düzenlemeyle isim değişikliğine gidilerek Jandarma Genel Komutanlığı adıyla çağdaş bir teşkilât kuruldu, başına korgeneral rütbeli bir âmir tayin edildi. Birlikler sabit ve seyyar jandarma olmak üzere iki gruba ayrıldı. 1937'de çıkarılan kanunun tatbik şeklini gösteren Jandarma Teşkilat ve Vazife Nizamnamesi yürürlüğe girdi (TBMMZC, 5/17). 1939'da sabit ve seyyar jandarma birlikleri, jandarma eğitim birlikleri ve okullar şeklinde yeniden düzenlendi.

\section{İç Olayların Bastırılmasında Jandarma Teşkilatı}

Cumhuriyetin ilanından sonra Jandarma teşkilatı özellikle Doğu ve Güneydoğu Anadolu'da başlayan isyanlarla uğraştı. Bu isyanların ilki 7 Ağustos 1924'te Hakkâri valisinin esir düşmesi ve üç jandarmanın şehit olmasıyla başlayan Nasturi ayaklanmasıdır. İkincisi ise 13 Şubat ve 31 Mayıs 1925 tarihleri arasında gerçekleşen Şeyh Said ayaklanmasıdır. Bu ayaklanma nedeniyle 26 Şubat 1925 tarihinde Elaziz (Elazığ), Genç, Muş, Ergani, Dersim, Diyarbakır, Mardin, Urfa, Siverek, Siirt, Bitlis, Van, Hakkâri ve Malatya vilayetleriyle Erzurum'un Kiğı ve Hınıs kazalarında bir ay süreyle sıkıyönetim ilan edilmiştir (Serhat Hürkan, Altıok'un Şark Ucu Doğu ve Güneydoğu Anadolu'da CHP (1919-2009), s. 34-36). Şeyh Said isyanı 15 Nisan1925'de bastırılmasına rağmen sıkıyönetim kanununun süresi 1927 yllına kadar uzatılmaya devam etti. (Uzatılmasının nedeni Şeyh Abdullah, Raçkotan ve Reman, Pervari, Mutki, Birinci Ağrı ve 
İkinci Ağrı Dağı diye anılan isyanların vuku bulmasıydı). Olayları bastırmak amacıyla 1927 yılında Umumi Müfettişlikler kurulmaya başlandı. Tasarıya göre altı adet müfettişlik kurulması planlandı (Cemil Koçak, Umumi Müfettişlikler (1927-1952), s. 53-210). Bu müfettişliklerin görevleri; asayiş ve emniyeti sağlamak, kanun ve nizamnamelerinin uygulanmasını takip etmek, idari makamları denetlemek ve üç ayda bir merkeze rapor vermekti. Bu görevleri yerine getirebilmek için müfettişliklere birçok yetki tanınmışt: Asayişin korunması için bölgeleri dâhilinde bulunan bütün jandarma kuvvetlerini, dağıtma ve yerleştirebilme yetkisine sahip olup jandarma kumandanına emir verebilirler. Top ve makinalı ile donanmış her biri yüz kişilik beş bölükten oluşan jandarma kuvvetini yanlarında bulundurabilirlerdi (Murat Burgaç, Türkiye'de Müfettişliklerin Kurulması ve Trakya Umumi Müfettişliği, 2013, s. 147-150). Umumi Müfettişlik Teşkilatının kadrolarında 27 Kasım 1927 tarihli talimatnameye göre umumi müfettiş, başmüşavir, müşavir, ordu subayı, jandarma subayları ve inzibat memurları, şube müdürü, memurlar yer almaktayd1 (Düstur, 3.tertip. c. 9: 19).

Umumi Müfettişliklerin kurulmasıyla birlikte jandarma teşkilatları çıkan isyanları bastırma noktasında aktif rol almaya başladı. Özellikle isyanların çoğaldığı 1. Umumi Müfettişlik bölgesinde olaylar bastırılarak Jandarma birlikleri tarafindan önemi miktarda silah toplandı 1928 yllında 208, 1929'da 550, 1930'da 4070, 1931'de 3172, 1932'de ise 14949 toplam 22.949 silah toplatıldı 1932 yllında toplanan silahların 4437 si Beyazid ve Iğdır bölgesinde, 5957 si tüfek bir otomatik Viranşehir, Siverek, Urfa ve Diyarbakır bölgesinde, 1679 tüfek ve 1 otomatik Sason, Mutki, Kulp, Beşiri ve Garzan bölgesinde, 1016 tüfekte Suruç ve Bilecik bölgesinde toplandı. Ayrıca Giresun Vilayeti dâhilinde 1932 yılında 933 tüfek toplandı. Bu suretle bu tarihe kadar ülke içerisinde toplanan silah adedi 2 otomatik, 23882 tüfekten ibaretti. 1933 yllında Birinci Umumi Müfettişlik haricinde ilk altı ayda Giresun'da 563, Rize'de, 250, Trabzon'da 1278, Tokatta 34 toplam 2125 silah topland1 (BCA. 030.10.128.923.6.31).

Tablo 3. Ülke İ̧̧erisinde Asayiş Olaylar

\begin{tabular}{|c|c|c|c|c|c|c|c|c|c|}
\hline $\begin{array}{l}\text { Ait } \\
\text { Olduğu } \\
\text { Sene }\end{array}$ & $\begin{array}{l}\text { Siyasi } \\
\text { Şekavet }\end{array}$ & $\begin{array}{l}\text { Adi } \\
\text { Şekavet }\end{array}$ & $\begin{array}{l}\text { Yol } \\
\text { Kesmek }\end{array}$ & $\begin{array}{l}\text { Dağa } \\
\text { Adam } \\
\text { Kaldırmak }\end{array}$ & $\begin{array}{l}\text { Silahlı } \\
\text { Gasp }\end{array}$ & $\begin{array}{l}\text { Cebri } \\
\text { Sirkat }\end{array}$ & $\begin{array}{l}\text { Hayvan } \\
\text { Hirsizlığ1 }\end{array}$ & $\begin{array}{l}\text { Haneye } \\
\text { Taarruz }\end{array}$ & Katil \\
\hline 339 & & 25 & 42 & & 149 & 94 & 263 & 10 & 218 \\
\hline 340 & 332 & 331 & 563 & 78 & 2234 & 884 & 2993 & 200 & 3688 \\
\hline 341 & 169 & 231 & 131 & 368 & 2465 & 900 & 2710 & 150 & 2316 \\
\hline 926 & 5 & 130 & 204 & 16 & 778 & 200 & 500 & 677 & 1347 \\
\hline 927 & 4 & 85 & 904 & 104 & 483 & 87 & 400 & 373 & 778 \\
\hline 928 & 10 & 47 & 119 & 84 & 718 & 389 & 1389 & 380 & 2420 \\
\hline 929 & 5 & 55 & 145 & 6 & 641 & 379 & 587 & 387 & 2907 \\
\hline 930 & 10 & 40 & 233 & 5 & 670 & 327 & 584 & 489 & 2975 \\
\hline 931 & 2 & 30 & 330 & 19 & 645 & 500 & 1988 & 1988 & 988 \\
\hline 932 & 2 & 31 & 128 & 2 & 279 & 89 & 269 & 86 & 274 \\
\hline 933 & & 25 & 10 & & 20 & & 19 & 58 & 109 \\
\hline
\end{tabular}

1.Dünya Savaşı sonrasında ordunun diğer unsurları gibi jandarma teşkilatı da çok zor şartlar altında bulunuyordu. Milli Mücadele'nin başlangıç yıllarında bir kısım kuvveti ile Kuvayi Milliye'yi destekleyen ve güçlendiren Jandarma Teşkilatı düzenli ordunun kurulmasından sonra en seçkin personelini ve kuvvetini ordu emrine vermek suretiyle savaş süresince ordu ile birlikte savaşarak birçok personelini şehit vermişti. Ayrıca bu dönemde Şeyh Eşref, Ali Batı, Haçın, Bozkır, Anzavur, Düzce, Konya, Koçkiri, Yozgat ve Zile gibi ayaklanmalarda da önemli görevlerde bulunmuştu.

Cumhuriyetin ilanından 1933 yllına kadar olan olaylar incelendiğinde 1923 yllında siyasi olay yok denecek kadar azdır. 1924 yılında ise 332 olaya rastlanmış ve bu oran gitgide azalarak 1932 yılında 2 olaya düşmüştür. 1924 yllında eşkiyalık olayları 11.000 iken 1925 yllında artarak 46.000 yükselmiştir. (BCA.030.10.128.923.6) 1928 yllında daha da artarak 56.000 bini bulmuştur. Gerekli tedbirlerin alınmasıyla suç oranları azalarak 1932'de 950 civarına düşmüştür. Adi eşkıyalık olayları da 1923 yılında 25 olayla başlamış 1925 yllında 321 olaya yükselmiş 1932 yilında ise 31 olaya düşmüştür. Umumi müfettişliklerin kurulmasıyla haydut ve kaçakçıların da büyük kısmı yakalandı. Jandarma tarafindan 1929 y1lında Erzurum Vilayeti dahilinde faaliyet göstermekte iken gördüğü baskı sonucu Suriye'ye kaçan ve tekrar huduttan içeri giren Palulu Yadove çetesi, Rize Trabzon, Gümüşhane bölgelerinde soygunculuk ve haydutluk yapan Nüsret, İsmail, Koço Sürmeneli Ahmet, Çeteleri, Tokat bölgesinde Bel Dağlı İzzet çetesi, Cebelibereket (Osmaniye) vilayetinde asayişi bozan Kürt Fahri Çetesi, Kırşehir, Aksaray, Konya, Ankara çevresinde asayişi bozan Katil İlyas ve Kürt Osman Çetesi, Burdur, Muğla, Denizli, Antalya vilayetlerinde soygun yapan Katil Rıza çetesi, Konya, Afyon, Karahisar, İsparta, vilayetleri dahilinde soygun yapan Nedim çetesi, 
Ağn1 bölgesinde isyan faaliyetlerinde bulunan Altındiş Osman, Denizli, İsparta, Burdur, Afyon, bölgelerinde bulunan Ferik Osman Çeteleri imha edilmişti (BCA. 030.10.128.923.6.32).

Tablo 4. 1932-1949 Yillarna Ait Kaçakçullk Olaylar

\begin{tabular}{|c|c|c|c|c|c|c|c|c|c|c|c|c|c|c|c|c|c|c|c|c|}
\hline \multirow[b]{3}{*}{$0<2 y:$} & \multicolumn{6}{|c|}{ Han $i$} & \multicolumn{5}{|c|}{$y, 16 a, a$} & \multicolumn{2}{|c|}{$2 i t$} & \multicolumn{5}{|c|}{$0<d v g u$} & & \\
\hline & 1932 & 1933 & 193 & & 935 & 1936 & 1937 & 193 & 19 & & 1940 & 1942 & 1942. & 1943 & 1944 & 1945 & 1946 & 1947 & 1948 & 1949 \\
\hline & 4194 & 3846 & 480 & & $y / 50$ & yo51 & 3488 & 3586 & 3.1 & 688 & 2850 & 2.200 & 2.000 & 2050 & 2.650 & 2150 & 2149 & 3043 & 3350 & 3599 \\
\hline $\begin{array}{l}\text { Yakalanan } \\
\text { Ka }\{a k \in l:\end{array}$ & 4716 & 8204 & 6.78 & & 6.918 & $7_{359}$ & 2168 & 476. & 3.5 & 919 & 3.350 & 2800 & 3.350 & 3,200 & 3:350 & 2.500 & 2901 & 4/79 & 4273 & 3659 \\
\hline $\begin{array}{l}\text { yskalanan } \\
\text { silah: }\end{array}$ & 163 & 309 & 26 & & 180 & 269 & 161 & go & & 66 & 50 & 100 & so & 100 & .50 & 100 & 88 & 140 & 161 & 175 \\
\hline $\begin{array}{l}\text { ydkalandan } \\
\text { mermi: }\end{array}$ & 1647 & $y .4 y_{3}$ & 16.0. & & 2779 & 3857 & 1406 & 340 & 1.4 & 43 & 5.400 & 2050 & 1200 & 3.200 & 2750 & 6800 & 4346 & 18.888 & 11902 & 7330 \\
\hline 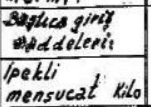 & 8789 & 10.566 & 5.55 & & 7996 & 7061 & 5032 & 579 & 7. & 000 & 2850 & 1550 & 800 & 600 & 200 & 200 & 152 & 2613 & 3331 & 3378 \\
\hline yünlü ... & 12.253 & 19.164 & y.25. & & 1218 & 1.759 & 1951 & 648 & 26 & 670 & 1.350 & 1000 & 400 & 250 & 800 & 510 & 184 & 790 & 651 & 536 \\
\hline Pamuklus. & 48.341 & 48.766 & 76.77 & & 23.331 & $45 / 137$ & $23 y / 2$ & 16.62 & 11.8 & 119 & 550 & 2.500 & 2550 & 2.200 & yoo & 3960 & 1446 & Yo2 & 509 & $24 j^{\prime}$ \\
\hline Eske elbise... & 4.083 & 2.661 & 2.18 & & 1776 & 1.319 & 2309 & 2.18 & 3 & 146 & 900 & 400 & 350 & 350 & 100 & 233 & 1778 & 3575 & 6084 & 7597 \\
\hline Akaryakit... & 48.341 & 19.92 & 17.55 & & 458 & 10.771 & 3398 & 1.4 & 1. & 64 & 2.550 & 17.150 & 14.150 & 12.500 & $25: 550$ & 6957 & 5911 & 3610 & 10.685 & 764 \\
\hline Cay vekahue. & $1-$ & - & 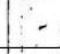 & & - & - & - & - & . & - & -se & $2 \cdot 200$ & 3.000 & $5: 600$ & 8.650 & 3850 & 5425 & 9160 & 16.614 & 11.063 \\
\hline $\begin{array}{l}\text { cakmak Je } \\
\text { cakmak tasc- }\end{array}$ & 87.919 & 159.18. & 102.6 & & 9.421 & 42550 & $30 / 45$ & 30.6 & 6. & 341 & 960 & 12.800 & 4.800 & 5.250 & 205.200 & 158.065 & 118.202 & 19.210 & 67.270 & $895 . / 85$ \\
\hline Sigara Kagidel & 604.188 & $10,24,2$ & 623424 & & 76,235 & $164 \% .170$ & 672.89 & 2539.3 & 380. & 812 & 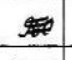 & - & - & - & - & - & - & 71.221 & 70868 & 207.269 \\
\hline $\begin{array}{l}\text { Gesitligümmot } \\
\text { esyast: kilo }\end{array}$ & 22.205 & 23.197 & 29.2 & & 2226 & 38.889 & 12.294 & 18.9 & II. & 876 & 16.500 & 12.450 & 23.900 & 9.900 & 10.000 & $21.4 / 5$ & 94\%1 & 14.733 & 4.230 & 22.633 \\
\hline $\begin{array}{l}\text { cessitligümrük } \\
\text { efyess 22. }\end{array}$ & - & - & $\therefore$ & & - & - & - & - & - & & - & 1.100 & - & 6.600 & 1.200 & 139500 & 17.988 & 25572 & 36.167 & 20.057 \\
\hline 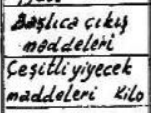 & 1538 & 61.118 & 23.60 & & 4.998 & 5170 & 3.993 & 2.876 & 1.7 & 148 & 500 & 25.450 & 54.000 & 35.000 & 51.450 & 38200 & 26.747 & $78: 112$ & 103.264 & $y \quad 21.25$ \\
\hline $\begin{array}{l}\text { Kesion hayva. } \\
\text { nc }\end{array}$ & 16.960 & 2.863 & 1.65 & & 154 & 5178 & 3.270 & 281 & 2. & 858 & 4.500 & 5.050 & 10.500 & 4000 & 11.400 & 6.800 & 3.300 & 11.082 & 19.515 & 8.926 \\
\hline Tütün kito & 12.064 & 35.37 & 15.99 & & (4/2) & 5839 & 2.841 & 1.30 & 4 & 971 & 1700 & 6 & - & 3.250 & 1350 & 700 & 3.366 & 8.574 & 9.147 & 17.576 \\
\hline $\begin{array}{l}\text { Uyusturveu } \\
\text { madde }\end{array}$ & 169 & 5.195 & 1.55 & & 3.369 & 1145 & 551 & 52 & & 292 & 500 & 1.050 & 150 & - & 250 & 866 & 344 & 1.587 & 1.377 & 3,379 \\
\hline $\begin{array}{l}\text { cossitli gumpoüt } \\
\text { esyess Kile }\end{array}$ & - & - & - & & - & $\tau$ & $=$ & - & & - & - & 5350 & 33.000 & 22450 & 21.400 & $\mid 3.7 / 3^{\prime}$ & 6.269 & 69976 & 13.311 & 6.190 \\
\hline$\ldots$... Aded & - & - & & & - & - & - & - & 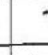 & & $\therefore$ & - & 6.750 & 9.150 & 10.900 & 35.553 & $15.1 Y_{7}$ & 24.064 & 20.767 & $7 / 6.731$ \\
\hline $\begin{array}{l}\text { cessitli kilo } \\
\text { tekel }\end{array}$ & 38.366 & 124.34 & 71.68 & & 860 & $1 / 302$ & 9494 & 185 & 21 & & 8.300 & 6.030 & 3.550 & 12.300 & 15.400 & 10.250 & 11.897 & 15.902 & 3.840 & 7.639 \\
\hline maddeleri Aded & 25.646 & 7536 & 408 & & 482 & 276 & 379 & 88 & 6 & 881 & 145.500 & 8.000 & 112.500 & 1.500 & 55.000 & 39.500 & 64.004 & 9.443 & 3.831 & 9.130 \\
\hline 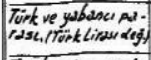 & 61.150 & 700.03 & g 16.5 & & 8.911 & 8709 & 22260 & 182.66 & 13. & 833 & 17.000 & 21.000 & Y0.000 & 34.000 & 97500 & 63.900 & 112.955 & 47521 & 140.134 & 250119 \\
\hline $\begin{array}{l}\text { Zaset dardac oug- } \\
\text { telifcins }\end{array}$ & 2.945 & 2.29 & 221 & & 1.499 & $2.67 y$ & 1.179 & 98 & & 863 & 750 & 2.100 & 2.450 & 2450 & 2050 & 1.650 & 1.107 & 2.411 & 2.275 & 1.216 \\
\hline & & & & & & & & & & & & . & & & & & & & & \\
\hline
\end{tabular}

Kaynak: BCA. 030.01.68.432.8

Gasp ve soygun olayları 1923'te 471, 1924 te 641,1927'de 1008, yükselmiş 1932 yllinda ise normal seviyelerine inerek 170 civarına düşmüştür. Cinayet olayları ise 1923'te 218, 1924'te 3689, 1925 yllinda 2316, 1932'de ise 276 civarındadır. (Cumhuriyet Jandarmas1, s. 37-39)

Tablo 5. Kaçakęcliğın Önlenmesi Bakemmindan Güney Hududunda Engel ve Yol Durumu

\begin{tabular}{|c|c|c|c|c|c|c|c|c|}
\hline \multirow[b]{2}{*}{ Y11 } & \multicolumn{4}{|c|}{ Sarfedilen } & \multicolumn{2}{|c|}{ Kapatılan Arazi } & \multirow{2}{*}{$\begin{array}{l}\text { Yeniden } \\
\text { Yapılan } \\
\text { Yol Km }\end{array}$} & \multirow{2}{*}{$\begin{array}{c}\text { Onarilan } \\
\text { Yol Km }\end{array}$} \\
\hline & Danert & $\mathbf{A} / \mathbf{P}$ & $\mathrm{A} / \mathrm{T}$ & - & Genişliği Km & $\begin{array}{l}\text { Uzunluğu } \\
\text { Km }\end{array}$ & & \\
\hline $955 / 956$ & 1.000 & 1.200 & 11.000 & & 350 & 60 & - & - \\
\hline $956 / 957$ & 9.000 & 28.000 & 13.300 & & 350 & 270 & 100 & 40 \\
\hline
\end{tabular}

Not: İstimlak edilecek sahipli arazi $200 \mathrm{~km}$ tülünde, 350 metre genişliğinde $70 \mathrm{~km}$ Karedir. İstimlak bedeli 5.000.000 lira olup 1957 bütçesinde tahsisatı alınmıştır.

Kaynak: BCA. 030.01.68.432.8.21 
Tablo 6. Jandarma Umum Kumandanliğını 1932-1949 Yillarnna Ait Kaçakçılık Olaylarna Ait İstatistike Bilgiler

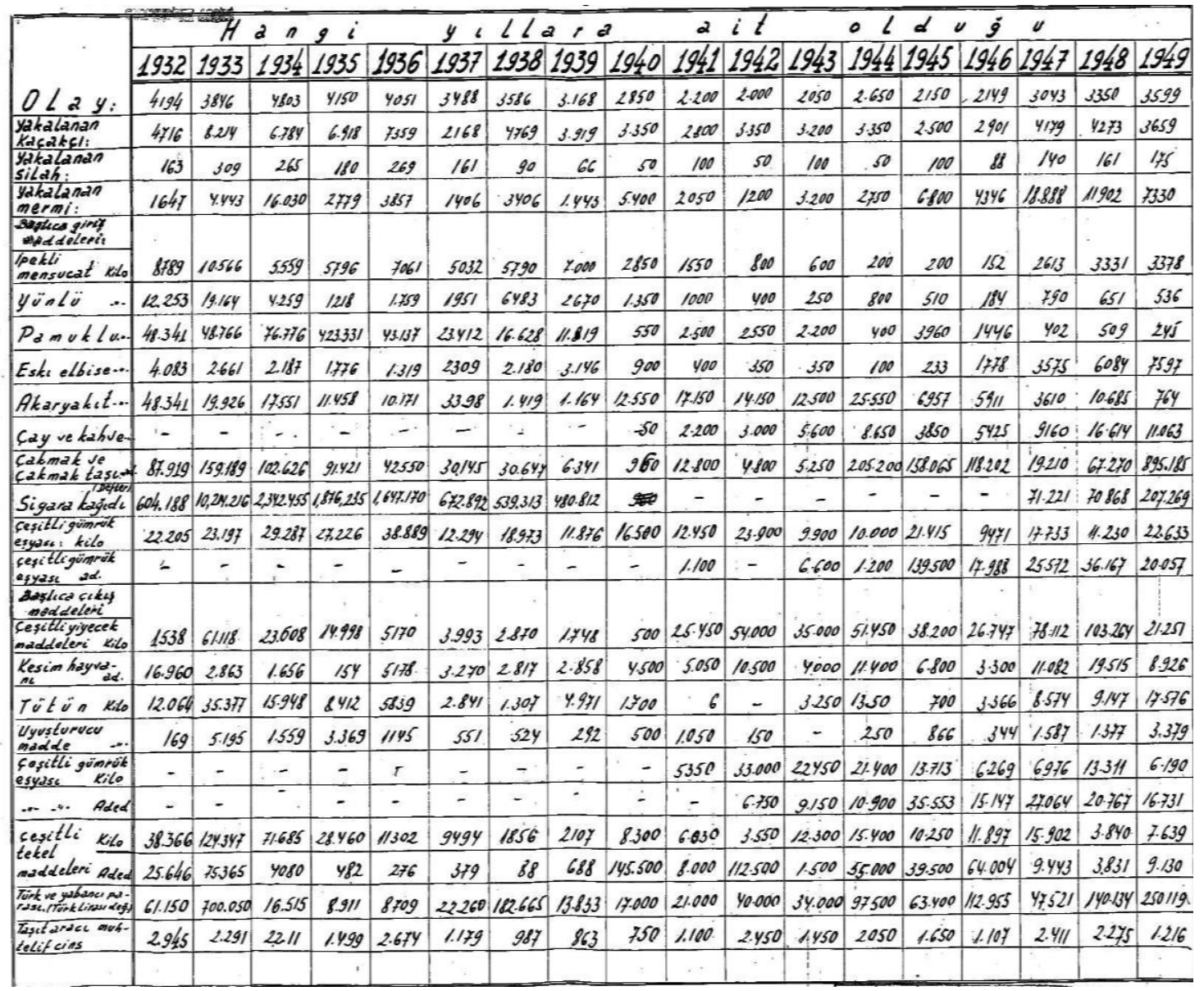

Kaynak: BCA. 030.01.68.432.8.20

Tablo 7. 1923-1938 Yil Vaka Olaylar

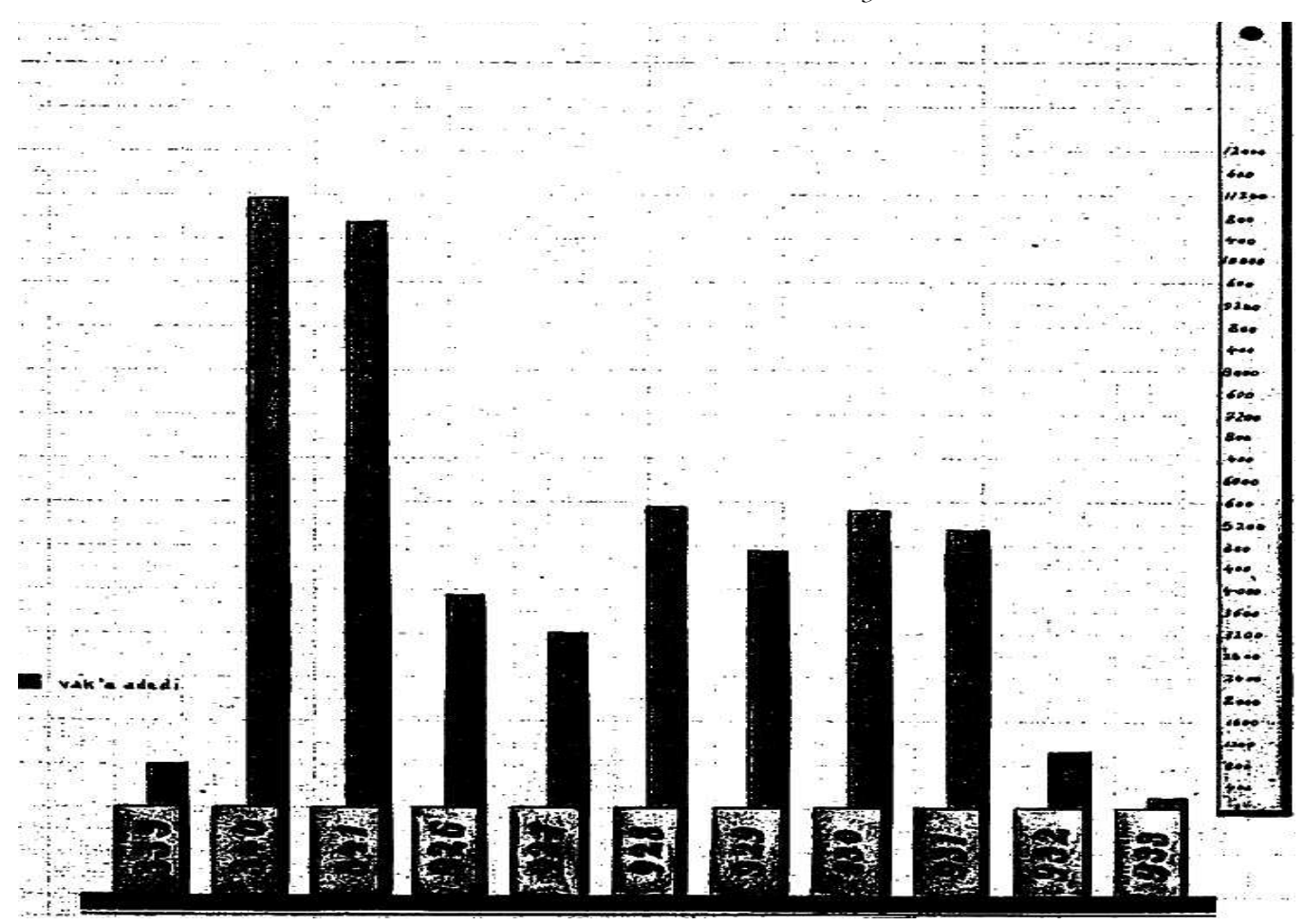




\section{Jandarma Teşkilatının Sıhhi Durumu}

Cumhuriyetin ilanı olan 29 Ekim 1923'ten 1925 tarihine kadar Jandarma Teşkilatında sıhhi işleri görecek bir birim yoktu. 1925 yllında Jandarma Teşkilatında sağlık işlerini yürütmek üzere kadroya başhekimlik ilave edildi. Jandarma Teşkilatında doğrudan bir hekim kadrosu yoktu. Seyyar taburlar ile başhekim tayin edilmekte M1. Tabur ağır makinalı tb ve okulların başhekimleri ve başhekim muavinleri hariç diğer kişiler serbest sivil doktorlardan ücretle tedavi olmaktaydılar. Jandarma revirleri her seyyar taburda onar, okullarda 20 ile 30 yataktan oluşmaktaydı. Çanakkale'de bulunan beş jandarma okulu için 1931 yllında 60 yataklı bir hastane tesisi edilmişti sonraki yıllarda hasta kapasitesi 80'e çıkarıldı (BCA.030.10.128.523.6).

Tablo 8. Jandarma Teşkilatınn 1923-1949 Yillarna Ait Sibhi İstatistik Cetveli

\begin{tabular}{|c|c|c|c|c|c|c|c|c|c|c|c|c|c|c|c|c|}
\hline \multirow{2}{*}{$\frac{y_{121}}{1923}$} & \multicolumn{2}{|c|}{ 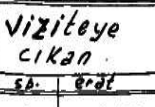 } & \multicolumn{2}{|c|}{$\begin{array}{l}\text { istirahat } \\
2 \text { alan } \\
\text { sb- enat }\end{array}$} & \multicolumn{2}{|c|}{ 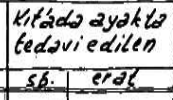 } & \multicolumn{2}{|c|}{$\begin{array}{l}\text { Mostanelere } \\
\text { gidence } \\
\text { spit erot }\end{array}$} & \multicolumn{2}{|c|}{ 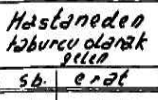 } & \multicolumn{2}{|c|}{$\begin{array}{l}\text { Hrodegisimi } \\
\text { ne gidencer. } \\
\text { sb. endet }\end{array}$} & 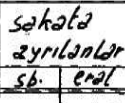 & 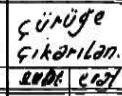 & \multicolumn{2}{|c|}{ 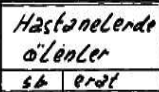 } \\
\hline & 125 & 29682 & 115 & 27.476 & 115 & $24 \times 7.6$ & 10 & 2215 & 8 & 1215 & 2 & 628 & 56 & 32 & 2 & 19 \\
\hline 1924 & 310 & 30.176 & 133 & 21.918 & $14 z$ & 29.962 & 163 & 3214 & $\beta_{2}$ & 1681 & 52 & 1100 & 89 & 57 & 3 & 27 \\
\hline 1925 & 383 & 44142 & 87 & 21918 & 309 & 33.428 & 74 & 10.744 & 149 & So24 & 57 & 1784 & 146 & 37 & 2 & $\sqrt{2}$ \\
\hline 1926. & $4 y 9$ & 4.900 & 105 & 25.572 & 352 & 34.676 & 177 & $14 \cdot 21.0$ & 137 & 11.080 & 37 & 1756 & 158 & yo & d. & 66 \\
\hline 1924 & 339 & 49.115 & 153 & 24.027 & 253. & $36 \cdot 426$ & 226 & 11.638 & 156 & 13.857 & 60 & 2012 & 186 & 59 & 3 & 59 \\
\hline 1928 & $4 / 3$ & 48.895 & 120 & 32.566 & 219 & 35.329 & 143 & 13.566 & 265 & $11: 896$ & 62 & 2125 & 162 & 64 & 2 & 65 \\
\hline 1928 & 447 & 45.932 & 53 & 20.540 & 317 & 33.440 & 130 & 12.491 & 136 & 10.766 & 87 & 1782 & 112 & 88 & 4 & 61 \\
\hline 1930 & 370 & 51.859 & 61 & 21.585 & 195 & 38.648 & 183 & 13.269 & 128 & 10.880 & 77 & 1781 & III & 89 & 2 & 60 \\
\hline 1931 & 310 & 61.921 & 133 & 31.618 & $14 y$ & 44.364 & 163 & 14.557 & $\rho_{2}$ & 12.284 & 55 & 2233 & 152 & 101 & 1 & 32 \\
\hline 1928. & $4 / 2$ & 53.423 & $1 / 5$ & 31.422 & 287 & 35.599 & 125 & 17824 & 87 & 14.122 & 66 & 3683 & 132 & 115 & 3 & 46 \\
\hline 1933 & 365 & 54.934 & 86 & 29.531 & 243 & 40.338 & $1 / 22$ & 14.596 & 88 & 12.195 & 62 & 9534 & 119 & 96 & 2 & 85 \\
\hline 1934 & $4 / 3$ & 60877 & 120 & 29.682 & 219 & 47.682 & 143 & 12.215 & 265 & 44.480 & 66 & 1206 & 9 & 32 & 1 & 78 \\
\hline 1935 & $4 / 5$ & 59285 & 132 & 31.832 & 283 & 42.523 & 132 & 16.762 & 126 & 12.765 & 92 & 8484 & 132 & 112 & 1 & 48 \\
\hline 1996 & 446 & $60.877^{\prime}$ & 200 & 29.682 & 200 & 11.476 & 181 & 12.215 & 265 & 44.480 & 30 & 1206 & 121 & 92 & 2 & 68 \\
\hline 1997 & 385 & 55.826 & 96 & 29.326 & 267 & 40.200 & 118 & 15.626 & 95 & 12. 425 & 74 & 5132 & 145 & 119 & 3 & 45 \\
\hline 1938 & $4 / 2$ & 53.423 & 115 & 31.422 & 287 & 35.599 & 125 & 17.824 & 87 & 14.122 & 66 & 3683 & 132 & $1 / 15$ & 2 & 16 \\
\hline 1939 & 399 & 62.132 & 85 & 33.59 & 282 & 43.504 & $1 / 7$ & 18.625 & 102 & 13.166 & 11 & 2248 & $i \sqrt{2}$ & 114 & 1 & 43 \\
\hline 1940 & $4 / 5$ & 59.285 & 132 & 31.832 & 283 & 42. 52$\}$ & 132 & 16.762 & 126 & 12.765 & 32 & 8484 & 132 & III & 3 & 37 \\
\hline (9421) & 395 & 48.895 & 116 & 32.566 & 282 & 35329 & 113 & 13.566 & 96 & 11.896 & 85 & 2125 & 162 & 108 & 2 & 35 \\
\hline 1942 & 444 & 45.932 & 53 & 20.540 & $3 / 7$ & 33.440 & 130 & 12.491 & 136 & 10.766 & 87 & 1782 & 112 & 88 & $y$ & 61 \\
\hline 19913 & 365 & $5 y \cdot 934$ & 86 & 29.531 & 243 & 40.338 & 122 & 14.596 & 88 & 12.195 & 62 & 9.534 & 119 & 96 & - & 42 \\
\hline 1944 & 310 & $61: 921$ & 133 & 31.618 & $14 \%$ & 44.364 & 163 & 12.557 & 92 & 12.284 & 55 & 2233 & 167 & 122 & 2 & 36. \\
\hline 19455 & 439 & 47.0 .83 & 212 & 23.107 & 258 & 35.205 & 144 & 10.531 & 119 & 9.470 & 28 & 1768 & 69 & 21 & 5 & 102 \\
\hline 1946 & 413 & 60.872 & 120 & 29.682 & 49 & $4 \% .682$ & 143 & 12.215 & 265 & 44.480 & 6 & 1206 & 91 & 20 & 2 & 85 \\
\hline 1947 & 457 & 61.217 & 126 & 26.993 & 302 & 46.175 & 256 & 19.609 & 205 & 15.263 & 36 & 2118 & 159 & 28 & 2 & $170^{\circ}$ \\
\hline 1948. & 339 & 49.115 & 193 & 24.027 & 253 & 36.426 & 226 & 17.638 & 156 & 13.857 & 60 & 2001 & 206 & 37 & 4 & $145^{\prime}$ \\
\hline 1949 & 449 & 49000 & 105 & 25.572 & 352 & 37.676 & 177 & 14.210 & $13 y$ & 111.080 & 37 & 1756 & 199 & 40 & 4 & 97 \\
\hline & & & & & & & & & & & & & & & & \\
\hline
\end{tabular}

1923 y1lından 1949 yılına kadarki Sıhhi istatistik cetveli incelendiğinde hastalık yüzünden sağlık ocaklarına gitme oranı II. Dünya Savaşı öncesi artmaya başlamıştır. Özellikle 1936 y1lı içerisinde 53 subay 43.669 er doktor muayenesi görmüştü. Bu kişilerden 13 subay 32.106 er ayakta 6.494 er revirde, 22 subay 4.320 er hastanelerde tedavi edilmişti. Bu kişilerden 9 subay 521 er hava tebdili, 96 er sakat 34 er çürük muamelesi görmüş 4 subay 127 erde çeşitli hastalıklardan ölmüştü. Ayrıca çarpışmalarda 25 er şehit düşmüştü. Bu suretle ölüm adedi 152 ere ulaşmış 2 subay 445 erde hastanelerde tedavi görmüştü (BCA. 030.10.128.923.17). 
Tablo 9. Jandarma Teşkilatında 1929-1932 Yullarında Görülen Hastalıklar

\begin{tabular}{|c|c|c|c|c|c|c|c|c|}
\hline \multirow{3}{*}{$\begin{array}{l}\text { Hastalık İsmi } \\
\text { Hazım Cihaz }\end{array}$} & \multicolumn{2}{|c|}{929} & \multicolumn{2}{|c|}{930} & \multicolumn{2}{|c|}{931} & \multicolumn{2}{|c|}{932} \\
\hline & Musap & Vefat & $\mathrm{M}$ & $\mathrm{V}$ & $\mathrm{M}$ & V & $\mathrm{M}$ & $\mathrm{V}$ \\
\hline & $585^{1}$ & 10 & 503 & 8 & 1236 & 9 & 905 & 6 \\
\hline Bronşit & 315 & 5 & 457 & 2 & 830 & 4 & 1102 & 6 \\
\hline Cilt Hastalık & 194 & 0 & 176 & 0 & 292 & 0 & 2020 & 0 \\
\hline Donma & 5 & 2 & 1 & 0 & 17 & 0 & 27 & 0 \\
\hline Zatülcenp & 66 & 3 & 33 & 4 & 113 & 10 & 101 & 10 \\
\hline Zatürre & 118 & 23 & 76 & 24 & 126 & 36 & 190 & 65 \\
\hline Romatizma & 100 & 0 & 111 & 0 & 168 & 2 & 293 & 1 \\
\hline Sair Aza Veremi & 15 & 0 & 24 & 6 & 78 & 18 & 36 & 4 \\
\hline Sitma & 1378 & 11 & 1153 & 6 & 1484 & 12 & 1381 & 21 \\
\hline Turukubevliye & 19 & 1 & 40 & 1 & 49 & 2 & 54 & 1 \\
\hline Asabi ve Akli & 21 & 0 & 27 & 1 & 41 & 1 & 57 & 2 \\
\hline Fit1k & 83 & 1 & 81 & 0 & 126 & 0 & 195 & 0 \\
\hline Kalp ve eviye & 27 & 2 & 13 & 2 & 93 & 7 & 58 & 7 \\
\hline Kulak & 121 & 0 & 152 & 0 & 211 & 1 & 267 & 0 \\
\hline Göz (trahi harici & 215 & 0 & 194 & 0 & 286 & 0 & 364 & 0 \\
\hline Güneş Urması & 15 & 0 & 2 & 0 & 6 & 0 & 7 & 0 \\
\hline Mafsal Çı1kması & 9 & 0 & 4 & 0 & 20 & 0 & 17 & 0 \\
\hline Kemik Kırı̆ğ & 15 & 0 & 20 & 1 & 29 & 0 & 17 & 1 \\
\hline Nezle Müstevliye & 62 & 0 & 65 & 0 & 199 & 0 & 664 & 1 \\
\hline Sair Hastalıklar & 2208 & 42 & 2029 & 32 & 3008 & 12 & 3805 & 37 \\
\hline Yekun & 5568 & 100 & 6161 & 87 & 8381 & 114 & 9561 & 162 \\
\hline
\end{tabular}

Hastalıklar içinde Sıtma hastalığı ilk sırada gelmektedir. Sıtma hastalığı bu dönemde ülkenin hemen hemen her bölgesinde yaygındı. Jandarma Teşkilatının da ülkenin her tarafinda bulunması sebebiyle Sitma hastalığından korunmak için hastalığın yoğun olarak görüldüğü bazı bölgelerde mayıs ayından başlamak ve eylül sonuna kadar devam etmek üzere haftada iki defa iki gram koruyucu olarak kinin verilmekteydi. Verilen bu koruyucu kinin ${ }^{2}$ tedavi gören erlerin cüzdanlarına da kayıt ettirilmekteydi. Sitmaya yakalananların tedavisi ise doktor bulunan yerlerde doktor nezareti gözetiminde yapılmaktaydı. Ayrıca karakollarda ve konakladığ1 yerlerde sıtma hastalığına yakalanmamalanı için bataklık olan bölgelerde koğuş ve odaların pencerelerine sivrisineğin girmesine mani olmak üzere tel kafes yaptırılmaktaydı (BCA.030.10.12.923.17.3). İkinci olarak bronşit ve göz hastalıkları gelmektedir. Ölüm oranlarında ise Zatürre önemli bir orandaydı. Salgın ve bulaşıc1 hastalıklardan korunmak için aşı yöntemine başvurulmuştur. Jandarma Teşkilatı genellikle açık arazide görev yaptığından mevsim ve hava değişiklikleri, kar yağmur gibi dış etkenlerden dolayı bulaşıcı hastalıklara tutulmaya daha çok maruz kalmaktaydılar. Göreve gidiş dönüşlerde ıslanıp üşüyerek solunum cihazı hastalıklarından ve zatürreden ölüm oranları yüksekti. Jandarma karakolları merkezden ve birçok yerde de hastanelerden uzak oldukları için yeterince tedavi imkanı bulamamaktaydılar. Ayrıca eşkıya ve çetelerle çatışmalardan dolayı ve Eşkıyalar ile çarpışmalarda düzenli bir cephe olmadığından yaralı ve ölü sayısı fazlaydı (BCA. 030.10.128.923.17.3).

\section{Jandarmanın Vasita Durumu}

Jandarma Teşkilatına ait ilk motorlu araç 1928 yılında 2 adet binek, 18 adet Mercedes- Benz kamyon 300 adet motosikletten ibaretti. Bu araçlardan iki adet binek ile üç adet kamyon merkez teşkilatının ihtiyacını karşılamak üzere Ankara'da bırakılmıştı. Diğer kamyonlar hudut birliklerine verilmişti (Cumhuriyet Jandarmas1, s. 73).

\footnotetext{
2 Kinin: kınakına ağacının kabuğundan elde edilen ve sıtmanın sağaltımında yararlanılan beyaz bir alkaloit; tuzlarından biri olan kinin sulfatı sözünden kısaltılarak halk arasında sulfata da denir.
} 


\section{Deniz Vasıtaları}

Tablo 10. 1929 Yulndan 1957 Yllına Kadar Jandarma Deniz Motorlarmı Gösterir Cetvel

\begin{tabular}{lll}
\hline Muayene Edildiği Tarih & Adedi & Aracin Cinsi \\
\hline 1929 & 6 & Karakol Motoru \\
$1929-1930$ & 10 & Açı Deniz Motoru \\
$1931-1932$ & 1 & Yelkenli Motor \\
1933 & 1 & Yelkenli Motor \\
1934 & 2 & Yelkenli Açı Deniz Motoru \\
1935 & 3 & Yelkenli Motor \\
1949 & 1 & Takip Motoru \\
1950 & 2 & Yelkenli Motor \\
1957 & 1 & Liman Motoru \\
1957 & 1 & Açk Deniz Motoru \\
\hline
\end{tabular}

Ülkemizin Sınır kıyı ve kara sularını muhafaza ve emniyetiyle kaçakçılığın men, takip ve tahkiki vazifelerinin dahiliye vekaletine devri hakkındaki 6815 sayılı kanunun uygulanması dolayısıyla Gümrük Muhafaza Umum Kumandanlığı emrinde bulunan bir kısım deniz vesaitleri bu dönemde Jandarma Umum Kumandanlığına devredilmişti. $\mathrm{Bu}$ dönemde teşkilat bünyesinde 23 deniz vasıtası mevcuttu (BCA.030.01.68.432.8). Ayrıca deniz araçlarının tamirlerini yapmak üzere kurulmuş birde atölye bulunmaktayd.

\section{Muhabere Cihazları}

Jandarma vazife ve hizmetlerinin ifasında muhabere kısmı ve cihazları önemli bir konumdaydı. Ülkenin her köșesine dağılmış bulunan Jandarma karakollarını haberleșme bakımından birbirine bağlayan ve hızlıca anlaşmayı sağlayan cihazlar bulunmaktaydı. Bu dönemde $47000 \mathrm{~km}$ uzunluğunda bir telefon muhabere şebekesi mevcut idi.

\section{Veteriner Hizmetleri}

Tablo 11. 1923-1947 Yullarnda Jandarma Birliklerine ait Hayvan Listesi

\begin{tabular}{|c|c|c|c|c|c|c|c|c|}
\hline Y11 & Binek & $\begin{array}{c}\text { NK. } \\
\text { Koşumu }\end{array}$ & Ceph. Koş. & Mekkare & $\begin{array}{l}\text { Hv. } \\
\text { Koş. }\end{array}$ & Mt. Koş & $\begin{array}{c}\text { Mubaya } \\
\text { Edilen }\end{array}$ & Toplam \\
\hline 1923 & 801 & 7 & 3 & 7 & 9 & 6 & 20 & 847 \\
\hline 1924 & 803 & 11 & 7 & 4 & 6 & 9 & 26 & 866 \\
\hline 1925 & 846 & 18 & 8 & 7 & 9 & 7 & 35 & 930 \\
\hline 1926 & 851 & 10 & 8 & 8 & 3 & 10 & 40 & 930 \\
\hline 1927 & 871 & 16 & 9 & 9 & 4 & 5 & 38 & 952 \\
\hline 1928 & 888 & 11 & 8 & 10 & 5 & 4 & 33 & 959 \\
\hline 1929 & 901 & 16 & 9 & 11 & 5 & 4 & 19 & 965 \\
\hline 1930 & 912 & 19 & 11 & 13 & 6 & 6 & 25 & 992 \\
\hline 1931 & 921 & 14 & 7 & 11 & 3 & 6 & 29 & 991 \\
\hline 1932 & 935 & 16 & 4 & 12 & 4 & 7 & 33 & 1011 \\
\hline 1933 & 945 & 41 & 10 & 15 & 9 & 7 & 39 & 1051 \\
\hline 1934 & 956 & 47 & 9 & 10 & 4 & 7 & 50 & 1083 \\
\hline 1935 & 951 & 46 & 6 & 9 & 3 & 5 & 59 & 1079 \\
\hline 1936 & 960 & 41 & 6 & 11 & 4 & 6 & 41 & 1069 \\
\hline 1937 & 961 & 40 & 7 & 10 & 6 & 4 & 41 & 1069 \\
\hline 1938 & 993 & 46 & 3 & 6 & 4 & 5 & 30 & 1087 \\
\hline 1939 & 982 & 43 & 7 & 16 & 2 & 7 & 39 & 1096 \\
\hline 1940 & 1100 & 51 & 5 & 7 & 3 & 6 & 45 & 1212 \\
\hline 1941 & 1111 & 66 & 6 & 9 & 4 & 8 & 39 & 1249 \\
\hline 1942 & 1146 & 71 & 3 & 7 & 3 & 10 & 53 & 1293 \\
\hline 1943 & 1190 & 60 & 6 & 9 & 3 & 9 & 80 & 1357 \\
\hline 1944 & 1201 & 50 & 7 & 10 & 3 & 16 & 55 & 1342 \\
\hline 1945 & 1211 & 55 & 7 & 11 & 6 & 12 & 73 & 1371 \\
\hline 1946 & 1250 & 61 & 6 & 13 & 6 & 9 & 60 & 1395 \\
\hline 1947 & 1305 & 61 & 8 & 17 & 2 & 12 & 66 & 1471 \\
\hline 1948 & 1401 & 65 & 10 & 17 & 2 & 11 & 110 & 1614 \\
\hline 1949 & 1450 & 71 & 11 & 18 & 3 & 12 & 147 & 1712 \\
\hline
\end{tabular}

Teşkilatın 1923 yılında kayıtlı 847 hayvanı bulunmaktaydı. Bu sayı her yıl \% 3 ile \%5 oranlarında artarak 1949 yllında 1712 ye yükseldi. Bu rakam Ortalama olarak her yll 65 hayvana denk gelmekteydi. 
ATLI

Tek Parti Döneminde Jandarma Teşkilatının Durumu (1923-1946)

\section{Bütçe Durumu}

1935 y1lı itibariyle jandarmanın bütçesi aktarmalarla 9.780.000 lira idi. 1936 yılında ise 9.000.000 liraya inmiştir. Karakol binaları ile birlikte Jandarmanın 1936'da 3.000 binası bulunmaktaydı.

Tablo 12. Jandarma Bütçe Durumu 1924-1949 Yillarna Ait Bütçe Durumu ve Yapılan Masraflarn Gösterir Ciz̧elge

\begin{tabular}{|c|c|c|c|c|}
\hline Senesi & $\begin{array}{l}\text { Alınan Tahsisat } \\
\text { A-1 }\end{array}$ & Yatırımlar & Toplam & Sarf edilen \\
\hline 1924 & 10.101 .096 & - & 10.101 .096 & 10.101 .096 \\
\hline 1925 & 11.077 .440 & - & 11.077 .440 & 11.077 .440 \\
\hline 1926 & 10.540 .000 & - & 10.540 .000 & 10.540 .000 \\
\hline 1927 & 9.197 .792 & - & 9.197 .792 & 9.197 .792 \\
\hline 1928 & 10.810 .577 & - & 10.810 .577 & 10.810 .577 \\
\hline 1929 & 8.945 .738 & - & 8.945 .738 & 8.945 .738 \\
\hline 1930 & 8.915 .649 & - & 8.915 .649 & 8.915 .649 \\
\hline 1931 & 8.723 .268 & - & 8.723 .268 & 8.723 .268 \\
\hline 1932 & 8.308.379 & - & 8.308 .379 & 8.308.379 \\
\hline 1933 & 8.679 .379 & - & 8.679 .379 & 8.679 .379 \\
\hline 1934 & 8.679 .379 & - & 8.679 .379 & 8.679 .379 \\
\hline 1935 & 9.289 .652 & - & 9.289 .652 & 9.289 .652 \\
\hline 1936 & 8.871 .980 & - & 8.871 .980 & 8.871 .980 \\
\hline 1937 & 10.210 .300 & - & 10.210 .300 & 10.210 .300 \\
\hline 1938 & 10.613 .470 & - & 10.613 .470 & 10.613 .470 \\
\hline 1939 & 11.013 .000 & - & 11.013 .000 & 11.013 .000 \\
\hline 1940 & 12.178 .640 & - & 12.178 .640 & 12.178 .640 \\
\hline 1941 & 13.631 .110 & - & 13.631 .110 & 13.631 .110 \\
\hline 1942 & 15.220 .615 & - & 15.220 .615 & 15.220 .615 \\
\hline 1943 & 26.778 .164 & - & 26.778 .164 & 26.778 .164 \\
\hline 1944 & 28.402 .467 & - & 28.402 .467 & 28.402 .467 \\
\hline 1945 & 17.729 .402 & - & 17.729 .402 & 17.729 .402 \\
\hline 1946 & 30.853 .758 & - & 30.853 .758 & 30.853 .758 \\
\hline 1947 & 37.234 .140 & - & 37.234 .140 & 37.234 .140 \\
\hline 1948 & 36.779 .569 & - & 36.779 .569 & 36.779 .569 \\
\hline 1949 & 42.937 .214 & - & 42.937 .214 & 42.937 .214 \\
\hline
\end{tabular}

Tablo 13. Jandarma Kumandanlı̆̆ının 1923-1949 Yıllar Arasındaki Onarm ve İnşa İsleri İle Bu Konuda Dağıtılan Ödenek Miktarm Gösteren Cizelge

\begin{tabular}{|c|c|c|c|c|}
\hline Sene & $\begin{array}{l}\text { İ. Umum K. } \\
\text { Bütçesi }\end{array}$ & Nafıa Vekâleti Yatırımı & Yeni İnşaatlar & Onarım \\
\hline 1923 & - & - & 1 & - \\
\hline 1924 & 11.500 & - & 7 & - \\
\hline 1925 & - & - & 4 & - \\
\hline 1926 & - & - & 9 & - \\
\hline 1927 & - & - & 8 & - \\
\hline 1928 & - & - & 10 & - \\
\hline 1929 & - & - & 11 & - \\
\hline 1930 & 15.000 & - & 30 & $\begin{array}{l}\text { Bütçenin } \% 10 \quad \text { nu } \\
\text { onarıma sarf edilmiştir. }\end{array}$ \\
\hline 1931 & 35.000 & - & 10 & - \\
\hline 1932 & 70.000 & - & 23 & - \\
\hline 1933 & 75.477 & - & 18 & - \\
\hline 1934 & 175.000 & - & 33 & - \\
\hline 1935 & 112.320 & - & 66 & - \\
\hline 1936 & 40.000 & 288.000 & 99 & - \\
\hline 1937 & 100.000 & 305.840 & 65 & - \\
\hline 1938 & 150.000 & 305.840 & 126 & - \\
\hline 1939 & 275.000 & 305.840 & 114 & - \\
\hline 1940 & 150.000 & 275.256 & 63 & - \\
\hline 1941 & 150.000 & 275.256 & 56 & - \\
\hline 1942 & 150.000 & 275.256 & 31 & - \\
\hline 1943 & 150.000 & 275.256 & 23 & - \\
\hline 1944 & 200.000 & 275.256 & 26 & - \\
\hline 1945 & 116.670 & 151.698 & 29 & 110 \\
\hline 1946 & 710.000 & 260.000 & 47 & 315 \\
\hline 1947 & 960.000 & 255.000 & 49 & 426 \\
\hline 1948 & 960.000 & 255.000 & 34 & 209 \\
\hline 1949 & 531.378 & - & 28 & 203 \\
\hline
\end{tabular}




\section{Jandarmanın Silah Durumu}

1930 yllinda jandarmanın elinde muhtelif cinste silahlar vardı. Bu silahlar gelişigüzel bir vaziyette kıtalara dağıtılmış idi. Yapılan çalışmalar sonucu mevcut silahlar tasfiye edilmiş mevcudu en fazla ve kullanıma elverişli yalnız dört cins silahın jandarmada bulunmasına karar verilmişti. Bekçi ve korucuların elinde çeşitli cinste ve ihtiyacın yarısı kadar silah vardı. Sonradan verilen 5000 tüfekle bekçi silah miktarı 23559 a çıkarıldı. (BCA.030.10.26.523.6.9) 1936 ylında alınan yüz bin liralık tahsilatla jandarmanın elinde bulunan bozuk silahların yenileri ile değiştirilmesine başlandı.

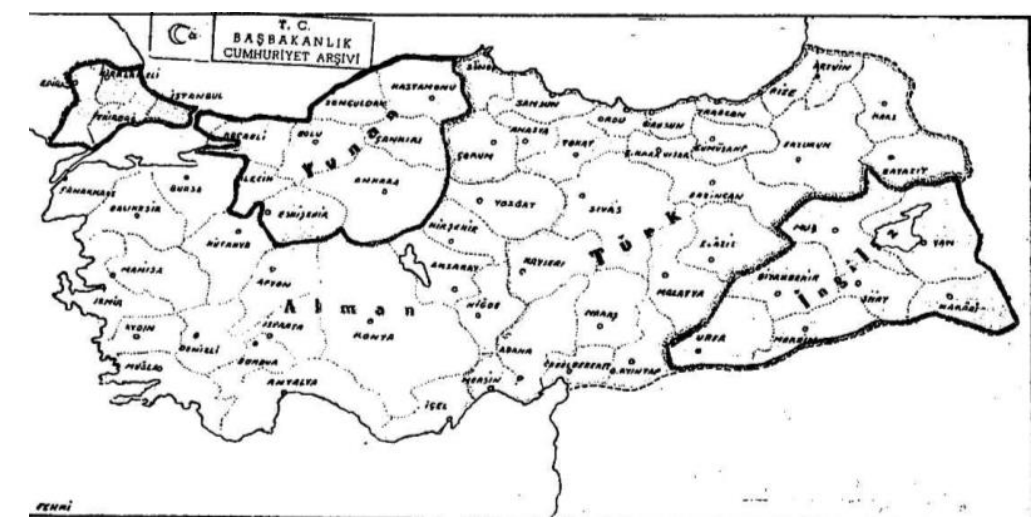

Şekil 2. Milli Mücadele Sonrası Jandarmada Bulunan Silablarn Bulunduklar Bölgeleri Gösteren Kroki

Kaynak: BCA. 030.10.128.313.6

\section{Tartışma, Sonuç ve Öneriler}

1286 (1870) yllına kadar Osmanlı İmparatorluğu dahilinde emniyet ve asayiş işleriyle ilgilenecek bir kurum bulunmamaktaydı. Bu döneme kadar İstanbul asayişi devletin hassa ordusu mahiyetinde olan yeniçeri kıtasından ayrılmış kuvvetler tarafından; eyaletlerin asayişi de valilerin hazari(Sulh ve asâyiş, sükun ve istirahat zamanlarına mensup ve müteallik) kuvvetlerini teşkil eden milis askerler tarafindan temin ediliyordu. Genel bir kumanda ve idare altına alacak bir kanun mevcut olmadığı gibi kumanda edecek bir resmi makamda yoktu. 1870 tarihinde ülkenin emniyet ve asayişini sağlamak üzere bir zaptiye nezareti kurulmuş ise de sadece İstanbul'la sınırlı kalmıştı. Türkiye Cumhuriyeti'nin sınırları dahilindeki Sabit Jandarma Teşkilatının esaslı kurulmasına 1912 yılında başlanmışı. Yabancı düzenleme heyetlerinin iştirakiyle kurulan komisyonlar ülkenin her tarafinda incelemede bulundu. 29 Ekim 1923'te Cumhuriyet'in ilanından sonra, devletin birçok kuruluşunda olduğu gibi, Jandarma Teşkilatı'nda da reorganizasyon çalışmalarına bir plan çerçevesi içerisinde başlanılmıştı.1918 ylında kapatılan Jandarma Astsubay Okulu İzmit'te yeniden açılmıştır. Sabit Jandarma Bölge Müfettişlikleri ve İl Jandarma Alay Komutanlıkları yeniden teşkilatlandırılmış, Seyyar Jandarma Birlikleri güçlendirilmiştir.

Cumhuriyetin ilanından sonra mevzuat yönünden en önemli gelişme 1930 yılında yaşandı. Jandarma Teşkilatı 22 Haziran 1930 tarih ve 1706 sayll kanunun yürürlüğe girmesiyle önemli bir aşama kaydetti. Bu kanunla jandarmanın tanımı, görevi, bağlllık durumu, yetkileri, subayların görev ve sorumlulukları ayrıntılı biçimde tespit edildi. Bu kanunla Jandarma Teşkilatı günümüze kadar sürecek hukuki statüsünü kazandı. Ayrıca bu tarihte sevk ve idaresi orduya bırakılan seyyar jandarma idaresinin de 1930 yıllnda yaşanan olaylardan dolayı sonraki yıllarda da orduya bırakılması kararlaştırıldı 1935 yılında Jandarma Teşkilatında önemli bir gelişme yaşandı. 1706 sayılı Jandarma Kanunu uyarınca Jandarma subaylarının Harp okulundan karşılanması esası kabul edildi. Böylece Jandarma teşkilâtının subay ihtiyacı Harp Okulu'ndan sağlanmaya başlandı. Ankara'da Anıttepe'de 1935'te Jandarma Sınıf Okulu açıldı ve uzun yıllar Polis Enstitüsü ile ortak binada öğretime devam etti. 1935 yllındaki yeni düzenlemeyle isim değissikliğine gidilerek Jandarma Genel Komutanlığı adıyla çağdaş bir teşkilât kuruldu, başına korgeneral rütbeli bir âmir tayin edildi. Birlikler sabit ve seyyar jandarma olmak üzere iki gruba ayrıldı. 1937'de çıkarılan kanunun tatbik şeklini gösteren Jandarma Teşkilat ve Vazife Nizamnamesi yürürlüğe girdi. 1939 yllında Jandarma Teşkilatı; Sabit Jandarma Birlikleri, Seyyar Jandarma Birlikleri, Jandarma Eğitim Birlikleri ve Okullar olmak üzere üç grup halinde yeniden düzenlenmiştir 
Cumhuriyetin ilanından sonra Jandarma teşkilatı özellikle Doğu ve Güneydoğu Anadolu'da başlayan isyanlarla uğraştı. Umumi Müfettişliklerin kurulmasıyla birlikte jandarma teşkilatları çıkan isyanları bastırma noktasında aktif rol almaya başladı. Özellikle isyanların çoğaldığı 1.Umumi Müfettişlik bölgesinde olaylar bastırılarak Jandarma birlikleri tarafindan önemi miktarda silah toplandı. Cumhuriyetin ilanı olan 29 Ekim 1923 'ten 1925 tarihine kadar Jandarma teşkilatında sıhhi işleri görecek bir birim yoktu. 1925 yllında jandarma teşkilatında sağlık işlerini yürütmek üzere kadroya başhekimlik ilave edildi. Jandarma teşkilatında doğrudan bir hekim kadrosu yoktu. Seyyar taburlar ile başhekim tayin edilmekte M1. Tabur ağır makinalı tb ve okulların başhekimleri ve başhekim muavinleri hariç diğer kişiler serbest sivil doktorlardan ücretle tedavi olmaktaydılar. Jandarma revirleri her seyyar taburda onar, okullarda 20 ile 30 yataktan oluşmaktaydı. Jandarma teşkilatına ait ilk motorlu araç 1928 yilında 2 adet binek, 18 adet Mercedes- Benz kamyon 300 adet motosikletten ibaretti. Bu araçlardan iki adet binek ile üç adet kamyon merkez teşkilatının ihtiyacını karşılamak üzere Ankara'da bırakılmıştı. Diğer kamyonlar hudut birliklerine verilmişti. Jandarma vazife ve hizmetlerinin ifasında muhabere kısmı ve cihazları önemli bir konumdaydı. Ülkenin her köşesine dağılmış bulunan Jandarma karakollarını haberleşme bakımından birbirine bağlayan ve hızlıca anlaşmayı sağlayan cihazlar bulunmaktaydı. Bu dönemde $47000 \mathrm{~km}$ uzunluğunda bir telefon muhabere şebekesi mevcut idi.

1930 yllında jandarmanın elinde muhtelif cinste silahlar vardı. Bu silahlar gelişigüzel bir vaziyette kıtalara dağıtılmış idi. Yapılan çalışmalar sonucu mevcut silahlar tavsiye edilmiş mevcudu en fazla ve kullanıma elverişli yalnız dört cins silahın jandarmada bulunmasına karar verilmişti.

\section{Etik Beyan}

"Tek Parti Döneminde Jandarma Teşkilatını Durumu (1923-1946)" başlıklı çalışmanın yazım sürecinde bilimsel, etik ve alıntı kurallarına uyulmuş; toplanan veriler üzerinde herhangi bir tahrifat yapılmamış ve bu çalısma herhangi başka bir akademik yayın ortamına değerlendirme için gönderilmemiştir.

\section{Kaynakça}

Alyot Halim, Türkiye'de Zabita, Ankara, 1947, 142-143

Atatürk’ün Doğumunun Yüzüncü Yılında Türk Silahlı Kuvvetleri, Harita Genel Müdürlüğü, Ankara,1982. s. 311. Başbakanlık Cumhuriyet Arşivi (BCA)

BCA. 030.01.68.432.8

BCA. 030.01.68.432.8.20

BCA. 030.01.68.432.8.21

BCA. 030.10.128.923.17

BCA. 030.10.128.923.6.12

BCA. 030.10.128.923.6.2

BCA. 030.10.128.923.6.31

BCA. 030.10.128.923.6.32

BCA. 030.18.01.02.19.23.11

BCA.030.01.68.432.8.16

BCA.030.01.68.432.8.3

BCA.030.10.128.523.6

BCA.030.10.128.823.6

BCA.030.10.128.923.6

BCA.030.10.18.923.6.21

BCA.030.10.25.166.1

BCA. 030.10.128.923.17.3

BCA.030.01.68.432.8

BCA.030.10.26.523.6.9

BCA. 030.10.128.313.6

Burgaç, Murat, Türkiye'de Müfettişliklerin Kurulması ve Trakya Umumi Müfettişliği, Ankara, 2013, s. 147-150

Cumhuriyet Jandarmas1, İstanbul, 1974, s. 21-23

Düstur,3.tertip. c.9:19)

Hürkan, Serhat, Altıok'un Şark Ucu Doğu ve Güneydoğu Anadolu'da CHP (1919-2009), Ankara, 2009, s.34-36

Jandarma Genel Komutanlı̆̆ Tarihi, C. I, Ankara, 2002, s.132.

Işık, Hüseyin Birinci Dünya Savaşında Seyyar Jandarma Birlikleri, Ankara, 1999, s. 9)

Koçak, Cemil, Umumi Müfettişlikler (1927-1952), İstanbul, 2010, s.53-210

Resmi Gazete, 22.06.1930 No: 1526.

Varlık, M.Bülent, Umumi Müfettişler Toplantı Tutanakları-1936, Ankara, 1937, s. 32.

TBMMZC, 20/72/86;

TBMMZC, $5 / 17$, 
Türk Silahlı Kuvvetleri Tarihi TBMM Hükümeti Dönemi (1920-1923). Türk İstiklâl Harbi Özet Tarihi, Genelkurmay ATASE Başkanlığı yayını, Ankara, 2001.s. s. 391.

\section{EXTENDED ABSTRACT}

The Gendarmerie Organization was established on November 3, 1839, in accordance with the article of the Tanzimat Fermanı on the protection of safety lives, rape and honor and property, and the duty of officers who did not have a central organization in the provinces. The starting year of 1839 was accepted as the Gendarmerie Organization Day, which was combined with the 14th of June, the date of the Asakiri Zaptiye Ordinance. Until 1870, there was no independent organization within the Ottoman Empire to engage in security and public affairs. Up to this date, the order of Istanbul was provided by the forces separated from the janissary continent, which was the Hassa Army of the state, and the order of the provinces was provided by the militia soldiers that constitute the hazards of the governors. There was no general command and law. Although there was a gendarmerie organization established in the 1870s, it was mostly on the axis of Istanbul. The name of the gendarmerie entered the Turkish state organization for the first time in history with the regulation adopted on 15 April 1880

Until 1286 (1870), there was no institution within the Ottoman Empire to deal with security and public affairs. Until this period, the public order in Istanbul by the forces of the state separated from the janissarycontinent; the public order of the provinces was provided by the militia soldiers who formed the hazari (peace and order, peace and resting time) of the governors. There was no general command and no law to control it, and no official authority to command it. In 1870, a conquest was established to ensure the safety and security of the country, but it was limited to Istanbul. Based on the establishment of the Republic of Turkey within the limits of the hard Gendarmerie it began in 1912. The commissions established with the participation of foreign regulatory committees examined all over the country. After the proclamation of the Republic on October 29, 1923, reorganization works were started within the framework of a plan in the Gendarmerie Organization as in many Other institutions of the state. The Gendarmerie Petty Officer School, which was closed in 1918, was reopened in Izmit. Fixed Gendarmerie Region alInspectors and Provincial Gendarmerie Regiment Commands were reorganized and the Mobile Gendarmerie Units were strengthened. Since the first days of the National Struggle Movement, the Mobile Gendarmerie Detachments, which have made significant contributions both to the establishment of public order and to it scontribution to the National resistance, occupied the agenda of the Turkish Grand National Assembly. While the abolition of mobile gendarmerie detachments was decided in the Turkish Grand National Assembly on 10 February 1921, the effective date was decided as the end of March 1921. In the absence of the Deputy Internal Medicine Act, the proposed law on the aforementioned detachments was adopted without further discussion. Article 94 of the 94 Law on the Elimination of Mobile Gendarmerie 94 dated 94 February 10, 1921; The mobile gendarmerie detachments are dated with the provision of "mobile gendarmerie detachments that are ordered by the lawdated 7 June 1336, which is mandated by the attorney of the National Defense for the procurement and public order of the defense country um.

The most important development in terms of legislation after the proclamation of the Republic took place in 1930. The Gendarmerie made a significant progress with the entry into force of Law no. 1706 of 22 June 1930. With this law, the definition of gendarmerie, duty, loyalty status, powers, duties and responsibilities of the officers were determined in detail. With this law, the Gendarmerie has gained its legal status that will continue until today. In addition, it was decided that the mobile gendarmerie administration, which was transferred to the army on this date, would be left to the army in the following years due to the events in 1930. In 1935, an important development took place in the Gendarmerie. In accordance with the Gendarmerie Law no. 1706, it was accepted that the Gendarmeri officers would be met from the Military School. Thus, the need of the officers of the Gendarmerie began to be provided from the Military School. In 1935, the Gendarmerie Class School was opened in Anittepe in Ankara and continued to teach in the common building with the Police Institute for many years. In 1935, a new organization was established under the name of the General Command of Gendarmerie by changing the name and a commander of the rank of Lieutenant General was appointed. The units were divided into twogroups as fixed and mobile gendarmerie. In 1937, the Gendarmerie Organization and Duties Regulation, which shows the application of the lawenacted, came into force. In 1939 the Gendarmerie Organization; Fixed Gendarmerie Units, Mobile Gendarmerie Units, Gendarmerie Training Units and Schools. 
After the proclamation of the Republic the Gendarmerie organization was particularly involved in the rebellions that started in Eastern and Southeastern Anatolia. With the establishment of General Inspectors, gendarmerie organizations began to take an active role in suppressing the riots. Especially in the 1st General Inspectorate region where the rebellion sincreased, the events were suppressed and a significant amount of weapons was collected by the Gendarmerieunits. From 29 October 1923 to 1925, the declaration of the Republic, there was no unit in the Gendarmerie to perform sanitary works. In 1925, the head physician was added to the staff to carry out the health affairs in the gendarmerie. There was no direct medical staff in the gendarmerie. Mobile battalions and chief physician are appointed M1. The battalion was being treated with fee from the civilian doctors and Other persons, except for the heavy machine technicians and the chief physicians of the schools and the assistant chief physicians. Gendarmerie in firmaries were repaired on every mobile battalion and 20 to 30 beds in schools. The first motor vehicle belonging to the gendarmerie in 1928, 2 passenger cars, 18 Mercedes-Benz truck sconsisted of 300 motorcycles. Two passenger cars and three trucks were left in Ankara to meet the needs of the central organization. The Other trucks were given to frontier troops. The communication part and equipment had an important role in the performance of the gendarmerie' sduties and services. There were device connecting the Gendarmerie stations scattered all over the country in terms of communication and providing quick agreement. There was a telephone communication network of $47000 \mathrm{~km}$. In 1930, the gendarmerie had weapons of various exes. These weapons were randomly distributed to the continents. As a result of the studies made, it was decided that only the four types of weapons available to the gendarmerie would have the maximum number of available weapons recommended. 